\title{
PEMODELAN REGRESI POISSON BIVARIAT PADA JUMLAH KEMATIAN IBU HAMIL DAN NIFAS DI JAWA TENGAH TAHUN 2017
}

\author{
Arbella Maharani Putri ${ }^{1}$, Alan Prahutama ${ }^{2}$, Budi Warsito ${ }^{3}$ \\ ${ }^{1,2,3}$ Departemen Statistika FSM Universitas Diponegoro \\ Alan.prahutama@gmail.com
}

\begin{abstract}
The maternal mortality rate is one of the indicators that determine the prosperity level of society in a country. Most of the maternal mortality caused by pregnancy maternal mortality and postpartum maternal mortality. Central Java is one of the provinces with the biggest number of pregnancy maternal mortality and postpartum maternal mortality in Indonesia. The number of pregnancy maternal mortality and postpartum maternal mortality follow Poisson Distribution and it has a significant correlation. Therefore, the writer analyzed factor that influences the number of pregnancy maternal mortality and postpartum maternal mortality using Univariate and Bivariate Poisson Regression method. Results from this study obtained that in the Univariate Poisson Regression variables that significantly influence pregnancy maternal mortality and postpartum maternal mortality are the percentage of pregnant women implementing $\mathrm{K} 1\left(\mathrm{X}_{1}\right)$, percentage of childbirth women that has puerperal health service $\left(\mathrm{X}_{6}\right)$ and percentage of household with clean and healthy behavior $\left(\mathrm{X}_{7}\right)$. In the Bivariate Poisson, the best model is the second model which assuming that covariance is an equation.
\end{abstract}

Keywords: Pregnancy of Maternal Mortality, Postpartum Maternal Mortality, Bivariate Poisson Regression.

\section{PENDAHULUAN}

Angka Kematian Ibu (AKI) merupakan salah satu indikator yang menentukan kesejahteraan masyarakat di suatu negara, khususnya berkaitan dengan masalah kesehatan ibu. Kasus kematian ibu banyak terjadi di negara-negara berkembang seperti Indonesia. Oleh karena itu, hal ini menjadi salah satu masalah yang harus diperhatikan oleh pemerintah Indonesia terutama mengenai kesehatan ibu.

Berdasarkan data Kementerian Kesehatan Republik Indonesia tahun 2015 AKI di Indonesia sebesar 305 per 100.000 kelahiran hidup (Kemenkes RI, 2018). Hal ini menjadi perhatian pemerintah sehingga Angka Kematian Ibu menjadi salah satu target dalam Sustainable Development Goals (SDG's) 2015 hingga 2030 dan Rencana Pembangunan Jangka Menengah Nasional (RPJMN) pada tahun 2019 (Bappenas, 2014).

Kematian ibu mencerminkan risiko yang dihadapi ibu selama masa kehamilan sampai dengan pasca persalinan yang dipengaruhi oleh status gizi ibu, keadaan sosial ekonomi, keadaan kesehatan menjelang kehamilan, kejadian berbagai komplikasi pada kehamilan dan kelahiran, tersedianya dan penggunaan fasilitas pelayanan kesehatan ternasuk pelayanan prenatal dan obstetri (Dinkes Jateng, 2018). Sebagian besar kematian ibu disebabkan oleh kematian ibu hamil dan kematian ibu nifas. Sebesar 60 persen kasus kematian ibu terjadi pada masa nifas dan 26,32 persen pada masa kehamilan (Dinkes Jateng, 2018).

Provinsi Jawa Tengah merupakan salah satu provinsi dengan jumlah kematian ibu hamil dan nifas yang cukup tinggi. Data dari Dinas Kesehatan Provinsi Jawa Tengah 
menunjukkan jumlah kematian ibu di Provinsi Jawa Tengah pada tahun 2017 sebanyak 475 kasus, dengan kasus kematian ibu hamil sebanyak 125, kematian ibu bersalin sebanyak 65 dan kematian ibu nifas sebanyak 285.

Berdasarkan permasalahan yang ada diduga bahwa tingginya jumlah kematian ibu hamil dan nifas di Jawa Tengah pada tahun 2017 dipengaruhi oleh beberapa faktor. Oleh karena itu, perlu dilakukan penelitian mengenai faktor-faktor yang mungkin berpengaruh terhadap kasus kematian ibu hamil dan nifas di Jawa Tengah menggunakan suatu alat yang sesuai dengan permasalahan. Data jumlah kematian ibu hamil dan nifas merupakan peristiwa jarang terjadi sehingga memiliki peluang kejadian yang kecil, selain itu peristiwa ini terjadi di suatu daerah tertentu sehingga mengikuti Distribusi Poisson. Selain itu, data jumlah kematian ibu hamil dan jumlah kematian ibu nifas diduga memiliki korelasi yang tinggi. Oleh karena itu, pemodelan yang tepat adalah dengan Regresi Poisson Bivariat.

\section{TINJAUAN PUSTAKA}

\subsection{Kematian Ibu Hamil dan Nifas}

Kematian ibu hamil adalah kematian ibu yang terjadi selama masa kehamilan yaitu dimulai dari konsepsi sampai lahirnya janin (Prawirohardjo, 2009). Kematian ibu nifas adalah kematian ibu yang terjadi selama masa nifas yaitu masa pulih kembali mulai dari persalinan selesai hingga alat-alat kandungan kembali seperti masa prahamil dengan lama masa nifas yaitu 6-8 minggu (Bahiyatun, 2008).

\subsection{Korelasi}

Koefisien korelasi adalah suatu pengukuran numerik untuk menilai besarnya hubungan linear antara dua variabel (Brase dan Brase, 2011). Hipotesis untuk uji signifikansi koefisien korelasi adalah sebagai berikut

$\mathrm{H}_{0}: \rho=0$ (korelasi sama dengan nol)

$\mathrm{H}_{1}: \rho \neq 0$ (korelasi tidak sama dengan nol)

Statistik Uji

$$
t=\frac{r \sqrt{n-2}}{1-r^{2}} \text { dengan } \quad r=\frac{\sum_{i=1}^{n}\left(x_{i}-\bar{x}\right)\left(y_{i}-\bar{y}\right)}{\sqrt{\sum_{i=1}^{n}\left(x_{i}-\bar{x}\right)^{2} \sum_{i=1}^{n}\left(y_{i}-\bar{y}\right)^{2}}}
$$

dengan taraf signifikansi $\alpha, \mathrm{H}_{0}$ ditolak jika $\left|t_{\text {hitung }}\right|$ dengan nilai $t_{\text {tabel }}$

\subsection{Multikolinieritas}

Suatu model regresi dikatakan terkena multikolinieritas apabila terjadi hubungan linier yang sempurna (perfect) atau pasti (exact) diantara beberapa atau semua variabel bebas dari suatu model regresi. Kasus multikolinieritas dapat diketahui dengan melihat nilai Variance Inflation Factors (VIF) yang bernilai lebih besar dari 10, dengan nilai VIF yang dinyatakan sebagai berikut

$V I F=\frac{1}{1-R_{i}^{2}}$

dengan $\mathrm{R}_{\mathrm{i}}{ }^{2}$ adalah koefisien determinasi antara variabel independen satu dengan variabel independen lainnya.

\subsection{Distribusi Poisson Univariat}

Distribusi poisson adalah suatu distribusi untuk peristiwa yang probabilitas kejadiannya kecil, dimana kejadiannya tergantung pada interval waktu tertentu atau di suatu daerah tertentu dengan hasil pengamatan berupa variabel diskrit. Variabel X dapat dikatakan berdistribusi poisson dengan parameter $\lambda$ memiliki fungsi probabilitas yang dinyatakan sebagai berikut (Myers, 1990).

$f(x, \lambda)= \begin{cases}e^{-\lambda} \frac{\lambda^{x}}{x !}, x=0,1,2, \ldots \\ 0 & , x \text { yang lain }\end{cases}$ 
dengan $\lambda$ adalah rata-rata variabel respon $\mathrm{X}$ yang berdistribusi poisson dan nilai rata-rata dan varians dari $\mathrm{X}$ mempunyai nilai lebih dari nol.

\subsection{Distribusi Poisson Bivariat}

Distribusi Poisson Bivariat terjadi ketika variabel terdapat variabel random $Z_{1}, Z_{2}$ dan $Z_{3}$ berdistribusi Poisson dengan parameter $\lambda_{1}, \lambda_{2}$ dan $\lambda_{3}$. Terdapat variabel random $Y_{1}$ dan $\mathrm{Y}_{2}$ yang terbentuk dari variabel $\mathrm{Z}_{1}, \mathrm{Z}_{2}$ dan $\mathrm{Z}_{3}$ yaitu $Y_{1}=\mathrm{Z}_{1}+\mathrm{Z}_{3}$ dan $Y_{2}=\mathrm{Z}_{2}+\mathrm{Z}_{3}$ sehingga $E\left(Y_{1}\right)=\lambda_{1}+\lambda_{3}$ dan $E\left(Y_{2}\right)=\lambda_{2}+\lambda_{3}$ dengan $\lambda_{3}$ merupakan kovarian antara $Y_{1}$ dan $Y_{1}$. Secara bersama-sama variabel random $Y_{1}$ dan $Y_{2}$ berdistribusi poisson bivariat memiliki fungsi probabilitas sebagai berikut (Karlis dan Ntzoufras, 2005).

$$
f\left(y_{1}, y_{2}\right)=\left\{\begin{array}{l}
e^{-\left(\lambda_{1}+\lambda_{2}+\lambda_{3}\right)} \frac{\lambda_{1}^{y_{1}}}{y_{1} !} \frac{\lambda_{2}{ }^{y_{2}}}{y_{2} !} \sum_{k=0}^{\min \left(y_{1}, y_{2}\right)}\left(\begin{array}{c}
y_{1} \\
k
\end{array}\right)\left(\begin{array}{c}
y_{2} \\
k
\end{array}\right) k !\left(\frac{\lambda_{3}}{\lambda_{1} \lambda_{2}}\right)^{k} ; y_{j}=0,1,2, \ldots \\
; y_{j} \text { yang lainnya }
\end{array}\right.
$$

\subsection{Uji Kecocokan Distribusi}

Salah satu metode uji kecocokan distribusi yang sering digunakan adalah uji Kolmogorov-Smirnov. Prinsip dari Uji Kolmogorov-Smirnov adalah menghitung selisih absolut antara fungsi ditribusi frekuensi kumulatif sampel $[\mathrm{S}(\mathrm{x})]$ dan fungsi distribusi frekuensi teoritis $\left[\mathrm{F}_{0}(\mathrm{x})\right]$ pada masing-masing interval kelas.

Hipotesis:

$\mathrm{H}_{0}$ : Data mengikuti distribusi Poisson

$\mathrm{H}_{1}$ : Data tidak mengikuti distribusi Poisson

Statistik Uji

$$
D=\operatorname{Sup}\left|S(x)-F_{0}(x)\right|
$$

dengan taraf signifikansi $\alpha, \mathrm{H}_{0}$ ditolak jika nilai $D>D_{(\alpha)} p$-value $<\alpha$.

\subsection{Regresi Poisson Univariat}

Model yang tepat untuk data diskrit (count) adalah model regresi Poisson yang merupakan model regresi nonlinier (Cameron dan Trivedi, 1998). Menurut Myers (1990) model Regresi Poisson ini menggunakan Generalized Linier Model (GLM) yaitu model regresi untuk data yang tidak mengikuti distribusi normal. Model Regresi Poisson Univariat untuk variabel $Y_{i}$ mengikuti Distribusi Poisson dengan parameter $\lambda_{i}$ adalah sebagai berikut

$\lambda_{i}=\exp \left(\boldsymbol{x}_{i}^{T} \boldsymbol{\beta}\right)$

dengan

$x_{i}$ adalah variabel independen yang dinotasikan dengan $\boldsymbol{x}_{\boldsymbol{i}}^{\boldsymbol{T}}=\left[\begin{array}{lllll}1 & x_{1 i} & x_{2 i} & \cdots & x_{k i}\end{array}\right]$

$\beta$ adalah paremeter regresi poisson yang dinotasikan dengan $\boldsymbol{\beta}^{\mathbf{T}}=\left[\begin{array}{lllll}\beta_{0} & \beta_{1} & \beta_{2} & \cdots & \beta_{k}\end{array}\right]$ sehingga

$\lambda_{i}=\exp \left(\beta_{0}+\beta_{1} x_{1 i}+\beta_{2} x_{2 i}+\cdots+\beta_{k} x_{k i}\right)$

Penaksiran parameter untuk regresi poisson univariat dilakukan dengan menggunakan metode Maximum Likelihood Estimation (MLE) dengan fungsi likelihood untuk regresi poisson univariat adalah sebagai berikut

$L(\boldsymbol{\beta})=\frac{e^{-\sum_{i=1}^{n} e^{\left(x_{i}{ }^{T} \boldsymbol{\beta}\right)}}\left(e^{\sum_{i=1}^{n} y_{i} x_{i}^{T} \boldsymbol{\beta}}\right)}{\prod_{i=1}^{n} y_{i} !}$

Bentuk logaritma dari fungsi likelihood adalah sebagai berikut.

$\ln L(\boldsymbol{\beta})=-\sum_{i=1}^{n} e^{\left(\boldsymbol{x}_{i}{ }^{T} \boldsymbol{\beta}\right)}+\sum_{i=1}^{n} y_{i} \boldsymbol{x}_{\boldsymbol{i}}{ }^{T} \boldsymbol{\beta}-\sum_{i=1}^{n} \ln \left(y_{i} !\right)$

Selanjutnya persamaan tersebut diturunkan terhadap $\boldsymbol{\beta}$ dan menghasilkan 
$\frac{\partial \ln L(\boldsymbol{\beta})}{\partial \boldsymbol{\beta}}=-\sum_{i=1}^{n} \boldsymbol{x}_{\boldsymbol{i}} e^{\boldsymbol{x}_{\boldsymbol{i}}^{T} \boldsymbol{\beta}}+\sum_{i=1}^{n} y_{i} \boldsymbol{x}_{\boldsymbol{i}}=0$

Namun cara tersebut tidak mendapatkan hasil yang eksplisit, sehingga alternatif untuk memaksimukan fungsi loglikelihood adalah dengan metode iterasi numerik NewtonRaphson.

Pengujian parameter dilakukan untuk mengetahui kesesuaian model yang terbentuk setelah diperoleh penaksir parameter pada model regresi poisson. Pengujian parameter dilakukan secara serentak maupun parsial.

Hipotesis

$\mathrm{H}_{0}: \beta_{1}=\beta_{2}=\ldots=\beta_{k}=0$

$\mathrm{H}_{1}$ : paling sedikit ada $\beta j \neq 0, j=1,2, \ldots, k$

Statistik Uji

$$
D(\widehat{\boldsymbol{\beta}})=-2 \ln \left\lfloor\frac{L(\widehat{\omega})}{L(\widehat{\Omega})}\right\rfloor
$$

Fungsi $L(\hat{\omega})$ adalah nilai maksimum likelihood untuk model tanpa melibatkan prediktor dan $L(\widehat{\Omega})$ untuk model lengkap. Kriteria pengujiannya adalah tolak $\mathrm{H}_{0}$ benar pada tingkat signifikansi $\alpha$ jika $D(\widehat{\boldsymbol{\beta}})>\chi_{(v, \alpha)}^{2}$ dengan $v$ adalah jumlah parameter di bawah populasi dikurangi jumlah parameter di bawah $\mathrm{H}_{0}$ benar. Jika terjadi penolakan $\mathrm{H}_{0}$ maka langkah selanjutnya adalah melakukan uji signifikansi parameter dengan hipotesis sebagai berikut.

$$
\begin{aligned}
& H_{0}: \beta_{j}=0 \\
& H_{1}: \beta_{j} \neq 0, \text { dengan } j=1,2, \ldots, k
\end{aligned}
$$

Statistik Uji

$$
Z=\frac{\hat{\beta}_{j}}{\operatorname{se}\left(\hat{\beta}_{j}\right)}
$$

Kriteria penolakan $\mathrm{H}_{0}$ dalam pengujian ini yaitu tolak $\mathrm{H}_{0}$ jika nilai $|\mathrm{Z}|>\mathrm{Z} \alpha / 2$.

\subsection{Regresi Poisson Bivariat}

Regresi poisson bivariat adalah metode yang digunakan untuk memodelkan sepasang count data yang berdistribusi poisson dan memiliki korelasi dengan beberapa variabel independen. Variabel $Y_{1 i}$ dan $Y_{2 i}$ mengikuti Distribusi Poisson Bivariat dengan parameter $\lambda_{1 i}, \lambda_{2 i}$, dan $\lambda_{3 i}$. Dalam kasus tersebut, regresi poisson bivariat mendapatkan model dari bentuk berikut.

$$
\text { dengan }
$$

$$
\lambda_{j i}=\exp \left(\boldsymbol{x}_{i}^{T} \boldsymbol{\beta}_{\boldsymbol{j}}\right)
$$

$x_{i}$ adalah variabel independen yang dinotasikan sebagai berikut

$$
\boldsymbol{x}_{\boldsymbol{i}}^{\boldsymbol{T}}=\left[\begin{array}{lllll}
1 & x_{1 i} & x_{2 i} & \cdots & x_{k i}
\end{array}\right]
$$

$\beta$ adalah vektor korespondensi koefisien regresi

sehingga

$$
\boldsymbol{\beta}_{j}=\left[\begin{array}{lllll}
\beta_{j 0} & \beta_{j 1} & \beta_{j 2} & \cdots & \beta_{j k}
\end{array}\right]^{T}
$$

$\lambda_{j i}=\exp \left(\beta_{j 0}+\beta_{j 1} x_{1 i}+\beta_{j 2} x_{2 i}+\cdots+\beta_{j k} x_{k i}\right)$

Hubungan antara Y dengan $\lambda_{j_{i}}$ dijabarkan sebagai berikut.

$$
\begin{aligned}
& \hat{y}_{i}=E(Y)+\varepsilon \\
& E\left(Y_{j}\right)=\lambda_{j i}+\lambda_{3} \\
& E\left(Y_{j}\right)=\exp \left(\boldsymbol{x}_{i}^{T} \boldsymbol{\beta}_{j}\right)+\lambda_{3}
\end{aligned}
$$

Dalam Regresi Poisson Bivariat terdapat 3 model dengan nilai $\lambda_{3}$ yang berbeda, diantaranya:

1. Model pertama adalah model dengan nilai $\lambda_{3}$ adalah suatu konstanta.

2. Model kedua adalah model dimana di dalam nilai $\lambda_{3}$ terdapat covariate. Nilai tersebut membentuk suatu persamaan yaitu $\lambda_{3}=\exp \left(\beta_{00}+\beta_{01} x_{1}+\cdots+\beta_{0 k} x_{k}\right)$. 
3. Model ketiga adalah model dengan nilai $\lambda_{3}$ adalah nol (0). Di dalam model ketiga dianggap tidak terdapat covariate dari dua buah variabel, biasanya model ini disebut model double poisson.

Penaksiran parameter pada regresi poisson bivariat menggunakan metode Maximum Likelihood Estimation (MLE) dengan fungsi likelihood sebagai berikut.

$L\left(\lambda_{3}, \boldsymbol{\beta}_{1}, \boldsymbol{\beta}_{2}\right)=\prod_{i=1}^{n}\left(\exp \left(-\lambda_{3}\right)-\exp \left(e^{x_{i}^{T} \boldsymbol{\beta}_{1}}-\lambda_{3}\right)-\exp \left(e^{x_{i}{ }^{T} \boldsymbol{\beta}_{2}}-\lambda_{3}\right)\right) \cdot W_{i}$

dengan

$W_{i}=\sum_{k=0}^{\min \left(y_{1}, y_{2}\right)} \frac{\lambda_{3}{ }^{\mathrm{k}}}{k !} \frac{\left(e^{x_{i}^{T} \boldsymbol{\beta}_{1}}-\lambda_{3}\right)^{y_{1 i}-k}\left(e^{x_{i}^{T} \boldsymbol{\beta}_{2}}-\lambda_{3}\right)^{y_{2 i}-k}}{\left(y_{1 i}-k\right) !\left(y_{2 i}-k\right) !}$

Fungsi likelihood dimaksimumkan menggunakan Algoritma Expectation-Maximization (EM). Algoritma EM terdiri dari dua tahap yaitu tahap Expectation dan tahap Maximization.

1. Tahap Expectation

Dalam tahap expectation yaitu menghitung nilai ekspektasi bersyarat dari data lengkap loglikelihood, dalam tahap ini menghitung nilai ekspektasi dari $\mathrm{Z}_{3 \mathrm{i}}$ untuk $i=$ $1,2 \ldots, n$ dengan cara sebagai berikut.

$$
s_{i}=\frac{\left(e^{x_{i}^{T} \boldsymbol{\beta}_{3}}\right)^{(m)}\left(\left(e^{x_{i}^{T} \boldsymbol{\beta}_{1}}-e^{x_{i}^{T} \boldsymbol{\beta}_{3}}\right)^{(m)}\right)^{-k}\left(\left(e^{x_{i}^{T} \boldsymbol{\beta}_{2}}-e^{x_{i}^{T} \boldsymbol{\beta}_{3}}\right)^{(m)}\right)^{-k}}{\sum_{k=0}^{\min \left(y_{1 i}, y_{2 i}\right)} \frac{\left(\left(e^{x_{i}{ }^{T} \beta_{3}}\right)^{(m)}\right)^{-k}\left(\left(e^{x_{i}{ }^{T} \boldsymbol{\beta}_{1}}-e^{x_{i} \boldsymbol{\beta}_{3}}\right)^{(m)}\right)^{-k}\left(\left(e^{x_{i} \boldsymbol{\beta}_{2}}-e^{x_{i} \boldsymbol{\beta}_{3}}\right)^{(m)}\right)^{-k}}{\left(y_{1 i}-k\right) !\left(y_{2 i}-k\right) ! k !}} . C
$$

dengan

$$
C=\sum_{k=0}^{\min \left(y_{1 i}, y_{2 i}\right)} \frac{\left(\left(e^{x_{i}^{T} \boldsymbol{\beta}_{3}}\right)^{(m)}\right)^{k}\left(\left(e^{x_{i}^{T} \boldsymbol{\beta}_{1}}-e^{x_{i}^{T} \boldsymbol{\beta}_{3}}\right)^{(m)}\right)^{-k}\left(\left(e^{x_{i}^{T} \boldsymbol{\beta}_{2}}-e^{x_{i}^{T} \boldsymbol{\beta}_{3}}\right)^{(m)}\right)^{-k}}{\left(y_{1 i}-1-k\right) !\left(y_{2 i}-1-k\right) ! k !}
$$

\section{Tahap Maximization}

Dalam tahap ini $\boldsymbol{\beta}$ dimaksimalkan dengan menghitung $\boldsymbol{\beta}^{(\mathrm{m}+1)}$ sebagai berikut

$\boldsymbol{\beta}_{1}{ }^{(\mathrm{m}+1)}=\widehat{\boldsymbol{\beta}}\left(\mathrm{y}_{1}-\mathrm{s}, \mathbf{W}_{1}\right)$,

$\boldsymbol{\beta}_{2}{ }^{(\mathrm{m}+1)}=\widehat{\boldsymbol{\beta}}\left(\mathrm{y}_{2}-\mathrm{s}, \mathbf{W}_{2}\right)$,

$\boldsymbol{\beta}_{3}{ }^{(m+1)}=\widehat{\boldsymbol{\beta}}\left(\mathrm{s}, \mathbf{W}_{3}\right)$,

$\lambda_{\mathrm{ji}}{ }^{(\mathrm{m}+1)}=\exp \left(\mathbf{W}_{\mathrm{ji}}^{\mathrm{T}} \widehat{\boldsymbol{\beta}}_{\mathrm{j}}^{(\mathrm{m}+1)}\right)$ untuk $j=1,2,3$

dengan $s=\left[s_{1} \ldots s_{n}\right]^{T}$ adalah vektor $n x 1$ yang didapatkan pada tahap $E, \widehat{\boldsymbol{\beta}}(y, \mathbf{W})$ yaitu estimasi Maximum Likelihood pada model poisson dengan respon vektor y dan data matriks W.

Pengujian parameter dilakukan untuk mengetahui kesesuaian model yang terbentuk setelah diperoleh penaksir parameter pada model regresi poisson. Pengujian parameter dilakukan secara serentak maupun parsial.

Hipotesis

$$
\begin{aligned}
& \mathrm{H}_{0}: \beta_{j 1}=\beta_{j 2}=\ldots=\beta_{j k}=0 \\
& \mathrm{H}_{1}: \text { paling sedikit ada } \beta_{j l} \neq 0, j=1,2 ; l=1,2, \ldots, k
\end{aligned}
$$

Statistik Uji

$$
D(\widehat{\boldsymbol{\beta}})=-2 \ln \left\lfloor\frac{L(\widehat{\omega})}{L(\widehat{\Omega})}\right\rfloor
$$

Kriteria pengujiannya adalah tolak $\mathrm{H}_{0}$ benar pada tingkat signifikansi $\alpha$ jika $D(\widehat{\boldsymbol{\beta}})>$ $\chi_{(v, \alpha)}^{2}$ dengan $v$ adalah jumlah parameter di bawah populasi dikurangi jumlah parameter di 
bawah $\mathrm{H}_{0}$ benar. Apabila terjadi penolakan $\mathrm{H}_{0}$ maka langkah selanjutnya adalah melakukan uji signifikansi parameter dengan hipotesis sebagai berikut.

$\mathrm{H}_{0}: \beta_{j l}=0$

$\mathrm{H}_{1}: \beta_{j l} \neq 0$, dengan $j=1,2 ; l=1,2, \ldots, k$

Statistik Uji

$$
Z=\frac{\hat{\beta}_{j l}}{\operatorname{se}\left(\hat{\beta}_{j l}\right)}
$$

Kriteria penolakan $\mathrm{H}_{0}$ dalam pengujian ini yaitu tolak $\mathrm{H}_{0}$ jika nilai $|\mathrm{Z}|>\mathrm{Z} \alpha / 2$.

\subsection{Metode Bootstrap untuk Mengestimasi Standar Error}

Menurut Cameron dan Trivedi (1998) algoritma bootstrap untuk mengestimasi standar error dari parameter adalah sebagai berikut.

1. Memilih B sampel independen bootstrap

2. Mengevaluasi replikasi bootstrap yang bersesuaian pada setiap sampel

3. Pembentukan model dari setiap replikasi

4. Menyimpan setiap nilai estimasi parameter dari hasil pemodelan dari setiap iterasi

5. Mengestimasi standar error dengan rumus berikut.

$$
s \hat{e}_{B o o t}=\sqrt{\frac{\sum_{j=1}^{B}\left[\hat{\beta}_{j}-\bar{\beta}_{j}\right]^{2}}{B-1}}
$$

dengan

B : banyaknya replikasi

$s \hat{e}_{\text {Boot }}$ : nilai estimasi standar error bootstrap

$\bar{\beta}_{j} \quad$ : nilai rata-rata hasil estimasi parameter, yaitu $\left(\sum_{j=1}^{B} \frac{\widehat{\beta}_{(j)}}{B}\right)$

$\hat{\beta}_{j} \quad$ : nilai estimasi parameter bootstrap ke-j, dimana $\mathrm{j}=1,2, \ldots, \mathrm{B}$

Banyak replikasi bootstrap untuk mengestimasi standar error biasanya berkisar antara 25200 atau B adalah 25 hingga 200.

\subsection{Akaike Information Criterion}

Akaike Information Criterion (AIC) merupakan salah satu kriteria untuk menentukan model terbaik. Semakin kecil nilai AIC, maka model semakin baik dan layak untuk digunakan. Nilai AIC dirumuskan pada persamaan berikut ini (Bozdogan, 2000)

$$
A I C=-2 \ln L(\tilde{\theta})+2 k
$$

$\mathrm{k}=$ banyaknya parameter yang digunakan

$L(\tilde{\theta})=$ nilai maksimal likelihood

\section{METODOLOGI PENELITIAN}

\subsection{Jenis dan Sumber Data}

Data yang digunakan dalam penelitian ini berupa data sekunder yang bersumber dari Laporan Profil Kesehatan Provinsi Jawa Tengah tahun 2017 yang dipublikasikan oleh Dinas Kesehatan Provinsi Jawa Tengah. Unit penelitian yang digunakan adalah kabupaten/kota di Jawa Tengah yang terdiri dari 29 kabupaten dan 6 kota, sehingga unit penelitian berjumlah 35 kabupaten/kota.

\subsection{Variabel Penelitian}

Variabel dependen yang digunakan terdiri variabel jumlah kematian ibu hamil dan jumlah kematian ibu nifas. Variabel independen terdiri variabel persentase ibu hamil melaksanakan Kunjungan Pertama $\left(\mathrm{X}_{1}\right)$, persentase ibu hamil melaksanakan Kunjungan Keempat $\left(\mathrm{X}_{2}\right)$, persentase ibu hamil mendapat tablet $\mathrm{Fe} 3\left(\mathrm{X}_{3}\right)$, persentase persalinan ditolong tenaga kesehatan $\left(\mathrm{X}_{4}\right)$, persentase komplikasi kebidanan yang ditangani $\left(\mathrm{X}_{5}\right)$, 
persentase ibu hamil mendapat pelayanan kesehatan nifas $\left(\mathrm{X}_{6}\right)$ dan persentase rumah tangga berperilaku hidup bersih dan sehat $\left(\mathrm{X}_{7}\right)$.

\subsection{Langkah-langkah Penelitian}

1. Membuat deskripsi data jumlah kematian ibu hamil dan jumlah kematian ibu nifas serta faktor-faktor yang mempengaruhinya pada setiap kabupaten/kota di Jawa Tengah tahun 2017 menggunakan statistika deskriptif.

2. Melakukan Uji Kecocokan Distribusi Poisson untuk setiap variabel dependen.

3. Melakukan Uji Korelasi untuk variabel dependen.

4. Melakukan Uji Multikolinearitas menggunakan kriteria VIF untuk mengetahui apakah antar variabel independen memiliki hubungan yang erat.

5. Melakukan pemodelan dengan regresi poisson univariat untuk masing-masing variabel dependen yang meliputi :

a. Mengestimasi parameter model regresi poisson univariat dengan memaksimumkan fungsi log-likelihood.

b. Melakukan pengujian signifikansi parameter secara serentak menggunakan Likelihood Ratio Test dan secara parsial menggunakan nilai $\mathrm{Z}$.

6. Melakukan pemodelan dengan regresi poisson bivariat yang meliputi :

a. Mengestimasi parameter model regresi poisson bivariat dengan memaksimumkan fungsi log-likelihood menggunakan algoritma ExpectationMaximization .

b. Menghitung nilai standar error parameter regresi poisson bivariat dengan metode bootstrap.

c. Melakukan pengujian signifikansi parameter secara serentak menggunkan Likelihood Ratio Test dan secara parsial menggunakan nilai $\mathrm{Z}$.

d. Menentukan model terbaik dengan metode AIC.

\section{HASIL DAN PEMBAHASAN}

\subsection{Statistika Deskriptif}

Tabel 1. Statistika Deskriptif

\begin{tabular}{|c|c|c|c|c|}
\hline Variabel & Rata-rata & Varian & Min & Max \\
\hline$Y_{1}$ & 3.57 & 11.08 & 0 & 15 \\
\hline$Y_{2}$ & 8.14 & 18.77 & 0 & 19 \\
\hline$X_{1}$ & 99.08 & 7.89 & 85.21 & 100 \\
\hline$X_{2}$ & 92.73 & 11.87 & 85.37 & 100 \\
\hline$X_{3}$ & 92.84 & 15.77 & 82.79 & 100 \\
\hline$X_{4}$ & 99.14 & 2.42 & 94.11 & 100 \\
\hline$X_{5}$ & 114.78 & 485.02 & 75.1 & 171.5 \\
\hline$X_{6}$ & 96.75 & 10.30 & 85.62 & 100 \\
\hline$X_{7}$ & 79.22 & 95.59 & 59.69 & 97.25 \\
\hline
\end{tabular}

\subsection{Uji Kecocokan Distribusi}

Pengujian kecocokan Distribusi Poisson untuk data jumlah kematian ibu hamil dengan hipotesis berikut

$\mathrm{H}_{0}$ : Data jumlah kematian ibu hamil mengikuti distribusi Poisson

$\mathrm{H}_{1}$ : Data jumlah kematian ibu hamil tidak mengikuti distribusi Poisson 
dengan taraf signifikansi $\alpha=0,05$ diperoleh nilai $\mathrm{D}_{\text {hitung }}=0,19898<\mathrm{D}_{\text {tabel }}=0,224$ dan $p$ value sebesar $0,1251>\alpha=0,05$ sehingga $\mathrm{H}_{0}$ diterima, maka data jumlah kematian ibu hamil mengikuti Distribusi Poisson.

Hipotesis untuk pengujian kecocokan Distribusi Poisson pada jumlah kematian ibu nifas adalah sebagai berikut

$\mathrm{H}_{0}$ : Data jumlah kematian ibu nifas mengikuti distribusi Poisson

$\mathrm{H}_{1}$ : Data jumlah kematian ibu nifas tidak mengikuti distribusi Poisson dengan taraf signifikansi $\alpha=0,05$ diperoleh nilai $\mathrm{D}_{\text {hitung }}=0,16436<\mathrm{D}_{\text {tabel }}=0,224$ dan $p$ value sebesar $0,3008>\alpha=0,05$ sehingga $\mathrm{H}_{0}$ diterima, maka data jumlah kematian ibu nifas mengikuti Distribusi Poisson.

\subsection{Uji Korelasi}

Regresi Poisson Bivariat dapat digunakan ketika kedua variabel dependen memiliki korelasi. Pada taraf signifikansi $\alpha=0,05$ diperoleh nilai $p$-value $=0,0074<\alpha=0,05$ dan $t_{\text {hitung }}=2,8541>t_{(33 ; 0,05)}=2,035$ maka $\mathrm{H}_{0}$ ditolak sehingga disimpulkan bahwa $\rho \neq 0$ sehingga ada hubungan yang signifikan antara variabel jumlah kematian ibu hamil dan jumlah kematian ibu nifas di Jawa Tengah tahun 2017. Nilai koefisien korelasi antara jumlah kematian ibu hamil dan jumlah kematian ibu nifas adalah sebesar 0,449.

\subsection{Uji Multikolinieritas}

Setelah melakukan Uji Korelasi langkah selanjutnya adalah melakukan pemeriksaan multikolinieritas untuk mengetahui apakah antara variabel independen memiliki hubungan yang erat.

Tabel 2. VIF Kasus Kematian Ibu Hamil

\begin{tabular}{cc}
\hline Variabel & VIF \\
\hline X1 & 1,92619 \\
X2 & 3,34991 \\
X3 & 2,73154 \\
X4 & 1,65882 \\
X5 & 1,90670 \\
X6 & 1,81538 \\
X7 & 1,83486 \\
\hline
\end{tabular}

Tabel 3. VIF Kasus Kematian Ibu Nifas

\begin{tabular}{cc}
\hline Variabel & VIF \\
\hline X1 & 1,70599 \\
X2 & 3,30153 \\
X3 & 2,43933 \\
X4 & 1,48243 \\
X5 & 1,63906 \\
X6 & 1,63003 \\
X7 & 1,61467 \\
\hline
\end{tabular}

Pada kasus kematian ibu hamil dan kasus kematian ibu nifas nilai VIF pada semua variabel independen kurang dari 10. Hal ini mengindikasikan bahwa tidak terjadi multikolinieritas pada variabel independen.

\subsection{Regresi Poisson Univariat pada Kasus Kematian Ibu Hamil}

Pengujian parameter pada Regresi Poisson Univariat dilakukan secara serentak maupun parsial. Berdasarkan nilai $D(\widehat{\boldsymbol{\beta}})=109,095$ lebih besar dari $\chi_{(7 ; 0,05)}^{2}=14,06713$ maka $\mathrm{H}_{0}$ ditolak paling sedikit ada satu variabel independen berpengaruh terhadap jumlah kematian ibu hamil di Jawa Tengah tahun 2017. Langkah selanjutnya adalah melakukan pengujian parameter secara parsial.

Tabel 4. Estimasi Parameter Kasus Kematian Ibu Hamil

\begin{tabular}{cccccc}
\hline Parameter & Estimasi & Standar Error & Z hitung & p-value & Keputusan \\
\hline$\beta_{0}$ & 15,7574 & 6,4389 & 2,4470 & 0,0144 & $\mathrm{H}_{0}$ ditolak \\
$\beta_{1}$ & $-0,1237$ & 0,0329 & $-3,7650$ & 0,0002 & $\mathrm{H}_{0}$ ditolak \\
$\beta_{2}$ & $-0,0166$ & 0,0455 & $-0,3660$ & 0,7147 & $\mathrm{H}_{0}$ diterima \\
$\beta_{3}$ & 0,0495 & 0,0372 & 1,3300 & 0,1834 & $\mathrm{H}_{0}$ diterima \\
$\beta_{4}$ & 0,0831 & 0,0703 & 1,1810 & 0,2375 & $\mathrm{H}_{0}$ diterima
\end{tabular}




\begin{tabular}{llllll}
$\beta_{5}$ & 0,0028 & 0,0050 & 0,5550 & 0,5792 & $\mathrm{H}_{0}$ diterima \\
$\beta_{6}$ & $-0,1228$ & 0,0294 & $-4,1750$ & 0,0000 & $\mathrm{H}_{0}$ ditolak \\
$\beta_{7}$ & $-0,0265$ & 0,0126 & $-2,1070$ & 0,0352 & $\mathrm{H}_{0}$ ditolak \\
\hline
\end{tabular}

Langkah selanjutnya adalah melakukan uji parameter secara parsial tanpa variabel yang tidak signifikan yaitu $\mathrm{X}_{2}, \mathrm{X}_{3}, \mathrm{X}_{4}$ dan $\mathrm{X}_{5}$.

Tabel 5. Estimasi Parameter Kasus Kematian Ibu Hamil Tanpa Variabel $X_{2}, X_{3}, X_{4}$ dan $X_{5}$

\begin{tabular}{cccccc}
\hline Parameter & Estimasi & Standar Error & $\mathbf{Z}$ hitung & p-value & Keputusan \\
\hline$\beta_{0}$ & 22,1887 & 3,5443 & 6,2600 & $3,84 \times 10^{-10}$ & $\mathrm{H}_{0}$ ditolak \\
$\beta_{1}$ & $-0,1027$ & 0,0236 & $-4,3450$ & $1,39 \times 10^{-5}$ & $\mathrm{H}_{0}$ ditolak \\
$\beta_{6}$ & $-0,0933$ & 0,0239 & $-3,9110$ & $9,18 \times 10^{-5}$ & $\mathrm{H}_{0}$ ditolak \\
$\beta_{7}$ & $-0,0231$ & 0,0099 & $-2,3370$ & 0,0195 & $\mathrm{H}_{0}$ ditolak \\
\hline
\end{tabular}

Berdasarkan tabel $5 \mathrm{H}_{0}$ ditolak untuk variabel persentase ibu hamil melaksanakan Kunjungan Pertama $\left(\mathrm{X}_{1}\right)$, persentase ibu nifas mendapatkan pelayanan kesehatan nifas $\left(\mathrm{X}_{6}\right)$ dan persentase rumah tangga berperilaku hidup bersih dan sehat $\left(\mathrm{X}_{7}\right)$ artinya variabelvariabel tersebut berpengaruh signifikan terhadap jumlah kematian ibu hamil di Jawa Tengah tahun 2017. Berdasarkan model umum Regresi Poisson Univariat

$$
\lambda_{i}=\exp \left(\beta_{0}+\beta_{1} x_{1 i}+\beta_{2} x_{2 i}+\cdots+\beta_{k} x_{k i}\right)
$$

Maka diperoleh model akhir sebagai berikut

$$
\hat{\lambda}=\exp \left(22,1887-0,1027 \mathrm{X}_{1}-0,0933 \mathrm{X}_{6}-0,0231 \mathrm{X}_{7}\right)
$$

\subsection{Regresi Poisson Univariat pada Kasus Kematian Ibu Nifas}

Dalam menentukan model regresi yang tepat pada Regresi Poisson Univariat terlebih dahulu dilakukan pengujian parameter secara serentak dan secara parsial. Berdasarkan nilai $D(\widehat{\boldsymbol{\beta}})=84,038$ lebih besar dari $\chi_{(7 ; 0,05)}^{2}=14,06713$ maka $\mathrm{H}_{0}$ ditolak secara serentak variabel independen berpengaruh terhadap jumlah kematian ibu nifas di Jawa Tengah tahun 2017. Langkah selanjutnya adalah melakukan pengujian parameter secara parsial. Hipotesis pada pengujian parameter secara parsial

Tabel 6. Estimasi Parameter Kasus Kematian Ibu Nifas

\begin{tabular}{cccccc}
\hline Parameter & Estimasi & Standar Error & Z hitung & p-value & Keputusan \\
\hline$\beta_{0}$ & 7,6789 & 4,3968 & 1,7460 & 0,0807 & $\mathrm{H}_{0}$ diterima \\
$\beta_{1}$ & $-0,0574$ & 0,0233 & $-2,4650$ & 0,0137 & $\mathrm{H}_{0}$ ditolak \\
$\beta_{2}$ & $-0,0194$ & 0,0311 & $-0,6220$ & 0,5338 & $\mathrm{H}_{0}$ diterima \\
$\beta_{3}$ & 0,0363 & 0,0240 & 1,5120 & 0,1304 & $\mathrm{H}_{0}$ diterima \\
$\beta_{4}$ & 0,0532 & 0,0450 & 1,1830 & 0,2370 & $\mathrm{H}_{0}$ diterima \\
$\beta_{5}$ & $-0,0058$ & 0,0035 & $-1,6700$ & 0,0950 & $\mathrm{H}_{0}$ diterima \\
$\beta_{6}$ & $-0,0495$ & 0,0208 & $-2,3840$ & 0,0171 & $\mathrm{H}_{0}$ ditolak \\
$\beta_{7}$ & $-0,0165$ & 0,0077 & $-2,1420$ & 0,0322 & $\mathrm{H}_{0}$ ditolak \\
\hline
\end{tabular}

Langkah selanjutnya adalah melakukan uji parameter secara parsial tanpa variabel yang tidak signifikan $\mathrm{X}_{2}, \mathrm{X}_{3}, \mathrm{X}_{4}$ dan $\mathrm{X}_{5}$.

Tabel 7. Estimasi Parameter Kasus Kematian Ibu Nifas Tanpa Variabel $X_{2}, X_{3}, X_{4}$ dan $X_{5}$

\begin{tabular}{cccccc}
\hline Parameter & Estimasi & Standar Error & $\mathbf{Z}$ hitung & p-value & Keputusan \\
\hline$\beta_{0}$ & 11,2858 & 2,5699 & 4,3920 & $1,13 \times 10^{-5}$ & $\mathrm{H}_{0}$ ditolak \\
$\beta_{1}$ & $-0,0394$ & 0,0181 & $-2,1770$ & 0,0295 & $\mathrm{H}_{0}$ ditolak \\
$\beta_{6}$ & $-0,0462$ & 0,0173 & $-2,6750$ & 0,0075 & $\mathrm{H}_{0}$ ditolak \\
$\beta_{7}$ & $-0,0106$ & 0,0063 & $-1,6740$ & 0,0941 & $\mathrm{H}_{0}$ diterima \\
\hline
\end{tabular}


Karena masih terdapat variabel yang tidak signifikan langkah selanjutnya adalah melakukan uji parameter secara parsial tanpa variabel yang tidak signifikan.

Tabel 8. Estimasi Parameter Kasus Kematian Ibu Nifas Tanpa Variabel $\mathrm{X}_{2}, \mathrm{X}_{3}, \mathrm{X}_{4}, \mathrm{X}_{5}, \mathrm{X}_{7}$

\begin{tabular}{cccccc}
\hline Parameter & Estimasi & Standar Error & $\mathbf{Z}$ hitung & p-value & Keputusan \\
\hline$\beta_{0}$ & 11,1290 & 2,5446 & 4,3740 & $1,22 \times 10^{-5}$ & $\mathrm{H}_{0}$ ditolak \\
$\beta_{1}$ & $-0,0391$ & 0,0176 & $-2,2210$ & 0,0264 & $\mathrm{H}_{0}$ ditolak \\
$\beta_{6}$ & $-0,0535$ & 0,0167 & $-3,2010$ & 0,0014 & $\mathrm{H}_{0}$ ditolak \\
\hline
\end{tabular}

Berdasarkan tabel $8 \mathrm{H}_{0}$ ditolak untuk variabel persentase ibu hamil melaksanakan Kunjungan Pertama $\left(\mathrm{X}_{1}\right)$ dan persentase ibu nifas mendapatkan pelayanan kesehatan nifas $\left(\mathrm{X}_{6}\right)$, artinya variabel-variabel tersebut berpengaruh signifikan terhadap jumlah kematian ibu nifas di Jawa Tengah tahun 2017. Pada Regresi Poisson Univariat untuk variabel jumlah kematian ibu nifas di Provinsi Jawa Tengah diperoleh nilai AIC sebesar 208,72. Berdasarkan model umum Regresi Poisson Univariat

$$
\lambda_{i}=\exp \left(\beta_{0}+\beta_{1} x_{1 i}+\beta_{2} x_{2 i}+\cdots+\beta_{k} x_{k i}\right)
$$

Maka model akhirnya adalah sebagai berikut

$$
\hat{\lambda}=\exp \left(11,1290-0,0391 \mathrm{X}_{1}-0,0535 \mathrm{X}_{6}\right)
$$

\subsection{Regresi Poisson Bivariat}

Jumlah kematian ibu hamil dan nifas mengikuti distribusi poisson dan memiliki korelasi positif yang signifikan. Selain itu, antara variabel independen tidak memiliki keterkaitan yang erat (multikolinieritas). Oleh karena itu, bisa dilakukan pemodelan jumlah kematian ibu hamil dan nifas menggunakan Regresi Poisson Bivariat.

Tabel 9. Estimasi Parameter Model Pertama

\begin{tabular}{ccccccc}
\hline \multirow{2}{*}{ Parameter } & \multicolumn{3}{c}{$\boldsymbol{\lambda}_{\mathbf{1}}$} & & \multicolumn{3}{c}{$\boldsymbol{\lambda}_{\mathbf{2}}$} \\
\cline { 2 - 7 } & Koefisien & SE & Zhitung & Koefisien & SE & Zhitung \\
\hline$\beta_{0}$ & 20,703 & 149,450 & 0,139 & 8,571 & 5,113 & 1,676 \\
$\beta_{1}$ & $-0,172$ & 1,531 & $-0,112$ & $-0,064$ & 0,032 & $-2,023^{*}$ \\
$\beta_{2}$ & $-0,029$ & 1,348 & $-0,022$ & $-0,026$ & 0,037 & $-0,693$ \\
$\beta_{3}$ & 0,080 & 0,696 & 0,115 & 0,046 & 0,029 & 1,547 \\
$\beta_{4}$ & 0,112 & 0,771 & 0,145 & 0,056 & 0,052 & 1,081 \\
$\beta_{5}$ & 0,004 & 0,054 & 0,077 & $-0,006$ & 0,004 & $-1,628$ \\
$\beta_{6}$ & $-0,169$ & 0,934 & $-0,181$ & $-0,057$ & 0,024 & $-2,422^{*}$ \\
$\beta_{7}$ & $-0,037$ & 0,676 & $-0,055$ & $-0,018$ & 0,009 & $-1,991^{*}$ \\
\hline
\end{tabular}

*) Signifikan pada taraf signifikansi $\alpha=0,05$

Pada model pertama dengan mengasumsikan kovarian merupakan suatu konstanta diperoleh nilai estimasi parameter untuk kovarian antara variabel jumlah kematian ibu hamil dan jumlah kematian ibu nifas sebesar 0,036 dengan nilai standar error sebesar 2,01.

$\hat{\lambda}_{1}=\exp \left(20,703-0,172 X_{1}-0,029 X_{2}+0,080 X_{3}+0,112 X_{4}+0,004 X_{5}-0,169 X_{6}-0,037 X_{7}\right)$

$\hat{\lambda}_{2}=\exp \left(8,571-0,064 X_{1}-0,026 X_{2}+0,046 X_{3}+0,056 X_{4}+0,006 X_{5}-0,057 X_{6}-0,018 X_{7}\right)$

$\hat{\lambda}_{3}=\exp (0,036)$

maka model untuk jumlah kematian ibu hamil adalah sebagai berikut.

$\mathrm{E}\left(Y_{1}\right)=\exp \left(20,703-0,172 X_{1}-0,029 X_{2}+0,080 X_{3}+0,112 X_{4}+0,004 X_{5}-0,169 X_{6}-0,037 X_{7}\right) \exp (0,036)$

Model untuk jumlah kematian ibu nifas adalah sebagai berikut.

$\mathrm{E}\left(Y_{2}\right)=\exp \left(8,571-0,064 X_{1}-0,026 X_{2}+0,046 X_{3}+0,056 X_{4}+0,006 X_{5}-0,057 X_{6}-0,018 X_{7}\right)+\exp (0,036)$

Pada pengujian serentak dengan taraf signifikansi $\alpha=0,05$ diperoleh nilai $D(\widehat{\boldsymbol{\beta}})=$ $346,6044>\chi_{(14 ; 0,05)}^{2}=23,6848$ maka $\mathrm{H}_{0}$ ditolak, artinya paling sedikit ada satu variabel independen yang berpengaruh terhadap jumlah kematian ibu hamil dan nifas di Jawa 
Tengah pada tahun 2017. Berdasarkan Tabel 9 diketahui bahwa untuk uji parsial semua variabel independen pada jumlah kematian ibu hamil $\mathrm{H}_{0}$ diterima karena nilai $\left|Z_{\text {hitung }}\right|<$ $Z_{(0,025)}=1,96$, artinya tidak ada variabel independen yang berpengaruh signifikan terhadap jumlah kematian ibu hamil. Pada jumlah kematian ibu nifas $\mathrm{H}_{0}$ ditolak untuk variabel persentase ibu hamil melaksanakan Kunjungan Pertama $\left(\mathrm{X}_{1}\right)$, persentase ibu nifas mendapatkan pelayanan kesehatan nifas $\left(\mathrm{X}_{6}\right)$ dan persentase rumah tangga berperilaku hidup bersih dan sehat $\left(\mathrm{X}_{7}\right)$ karena nilai $\left|Z_{\text {hitung }}\right|>Z_{(0,025)}=1,96$, artinya variabel tersebut berpengaruh secara signifikan terhadap jumlah kematian ibu nifas.

Tabel 10. Estimasi Parameter Model Kedua

\begin{tabular}{ccccccc}
\hline \multirow{2}{*}{ Parameter } & \multicolumn{2}{c}{$\lambda_{\mathbf{1}} *$} & \multicolumn{2}{c}{$\boldsymbol{\lambda}_{\mathbf{2}} *$} & \multicolumn{2}{c}{$\boldsymbol{\lambda}_{\mathbf{3}} *$} \\
\cline { 2 - 7 } & Koefisien & Zhitung & Koefisien & Zhitung & Koefisien & Zhitung \\
\hline$\beta_{0}$ & 36,404 & 0,041 & 12,983 & 1,412 & $-1088,9$ & $-0,597$ \\
$\beta_{1}$ & $-0,044$ & $-0,011$ & $-0,016$ & $-0,369$ & $-0,192$ & $-0,155$ \\
$\beta_{2}$ & $-0,036$ & $-0,004$ & $-0,042$ & $-0,887$ & 0,231 & 0,305 \\
$\beta_{3}$ & $-0,003$ & 0,000 & 0,024 & 0,644 & $-0,022$ & $-0,026$ \\
$\beta_{4}$ & $-0,166$ & $-0,028$ & $-0,030$ & $-0,347$ & 11,031 & 0,606 \\
$\beta_{5}$ & 0,021 & 0,020 & $-0,003$ & $-0,670$ & $-0,009$ & $-0,043$ \\
$\beta_{6}$ & $-0,112$ & $-0,022$ & $-0,031$ & $-0,748$ & $-0,114$ & $-0,074$ \\
$\beta_{7}$ & $-0,040$ & $-0,014$ & $-0,018$ & $-1,394$ & $-0,024$ & $-0,048$ \\
\hline
\end{tabular}

Berdasarkan Tabel 10 untuk model kedua dengan kovarian merupakan suatu persamaan diperoleh persamaan sebagai berikut

$$
\begin{aligned}
& \hat{\lambda}_{1} *=\exp \left(36,404-0,044 X_{1}-0,036 X_{2}-0,003 X_{3}-0,166 X_{4}+0,021 X_{5}-0,112 X_{6}-0,040 X_{7}\right) \\
& \hat{\lambda}_{2} *=\exp \left(812,983-0,016 X_{1}-0,042 X_{2}+0,024 X_{3}-0,030 X_{4}-0,003 X_{5}-0,031 X_{6}-0,018 X_{7}\right) \\
& \hat{\lambda}_{3} *=\exp \left(-1088,9-0,192 X_{1}+0,231 X_{2}-0,022 X_{3}+11,031 X_{4}-0,009 X_{5}-0,114 X_{6}-0,024 X_{7}\right)
\end{aligned}
$$

maka model untuk jumlah kematian ibu hamil adalah sebagai berikut.

$\mathrm{E}\left(Y_{1}\right)=\exp \left(36,404-0,044 X_{1}-0,036 X_{2}-0,003 X_{3}-0,166 X_{4}+0,021 X_{5}-0,112 X_{6}-0,040 X_{7}\right)+$ $\exp \left(-1088,9-0,192 X_{1}+0,231 X_{2}-0,022 X_{3}+11,031 X_{4}-0,009 X_{5}-0,114 X_{6}-0,024 X_{7}\right)$

Model untuk jumlah kematian ibu nifas adalah sebagai berikut

$$
\begin{gathered}
\mathrm{E}\left(Y_{2}\right)=\exp \left(812,983-0,016 X_{1}-0,042 X_{2}+0,024 X_{3}-0,030 X_{4}-0,003 X_{5}-0,031 X_{6}-0,018 X_{7}\right)+ \\
\exp \left(-1088,9-0,192 X_{1}+0,231 X_{2}-0,022 X_{3}+11,031 X_{4}-0,009 X_{5}-0,114 X_{6}-0,024 X_{7}\right)
\end{gathered}
$$

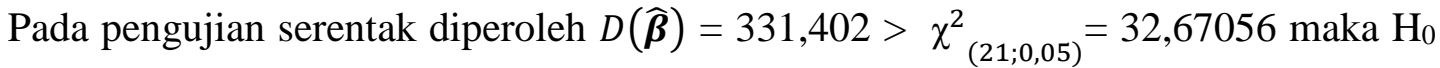
ditolak. Oleh karena itu, dapat disimpulkan bahwa paling paling sedikit ada variabel independen yang berpengaruh terhadap jumlah kematian ibu hamil dan nifas di Jawa Tengah pada tahun 2017. Berdasarkan tabel 11 diketahui bahwa untuk persamaan $\lambda_{1}, \lambda_{2}$ dan $\lambda_{3} \mathrm{H}_{0}$ diterima untuk semua variabel independennya karena semua nilai $\left|Z_{\text {hitung }}\right|<$ $\mathrm{Z}_{(0,025)}=1,96$, artinya tidak ada variabel indepeden yang berpengaruh signifikan terhadap jumlah kematian ibu hamil, jumlah kematian ibu nifas.

Tabel 11. Estimasi Parameter Model Ketiga

\begin{tabular}{ccccccc}
\hline \multirow{2}{*}{ Parameter } & \multicolumn{3}{c}{$\boldsymbol{\lambda}_{\mathbf{1}} * *$} & \multicolumn{3}{c}{$\boldsymbol{\lambda}_{\mathbf{2}} * *$} \\
\cline { 2 - 7 } & Koefisien & SE & Zhitung & Koefisien & SE & Zhitung \\
\hline$\beta_{0}$ & 15,757 & 6,313 & 2,496 & 7,679 & 4,440 & 1,730 \\
$\beta_{1}$ & $-0,124$ & 0,035 & $-3,578^{*}$ & $-0,057$ & 0,024 & $-2,415^{*}$ \\
$\beta_{2}$ & $-0,017$ & 0,043 & $-0,388$ & $-0,019$ & 0,029 & $-0,657$ \\
$\beta_{3}$ & 0,050 & 0,037 & 1,332 & 0,036 & 0,024 & 1,507 \\
$\beta_{4}$ & 0,083 & 0,077 & 1,081 & 0,053 & 0,044 & 1,202 \\
$\beta_{5}$ & 0,003 & 0,005 & 0,574 & $-0,006$ & 0,003 & $-1,758$
\end{tabular}




$\begin{array}{lllllll}\beta_{7} & -0,026 & 0,012 & -2,281^{*} & -0,017 & 0,008 & -2,188^{*}\end{array}$

*) Signifikan pada taraf signifikansi $\alpha=0,05$

Berdasarkan Tabel 11 diperoleh model ketiga dengan mengasumsikan nilai kovarian sama dengan nol diperoleh persamaan

$\hat{\lambda}_{1} * *=\exp \left(15,757-0,124 X_{1}-0,017 X_{2}+0,050 X_{3}+0,083 X_{4}+0,003 X_{5}-0,123 X_{6}-0,026 X_{7}\right)$

$\hat{\lambda}_{2} * *=\exp \left(7,679-0,057 X_{1}-0,019 X_{2}+0,036 X_{3}+0,053 X_{4}-0,006 X_{5}-0,049 X_{6}-0,017 X_{7}\right)$

maka model untuk jumlah kematian ibu hamil adalah sebagai berikut.

$\mathrm{E}\left(Y_{1}\right)=\exp \left(15,757-0,124 X_{1}-0,017 X_{2}+0,050 X_{3}+0,083 X_{4}+0,003 X_{5}-0,123 X_{6}-0,026 X_{7}\right)$

Model untuk jumlah kematian ibu nifas adalah sebagai berikut

$\mathrm{E}\left(Y_{2}\right)=\exp \left(7,679-0,057 X_{1}-0,019 X_{2}+0,036 X_{3}+0,053 X_{4}-0,006 X_{5}-0,049 X_{6}-0,017 X_{7}\right)$

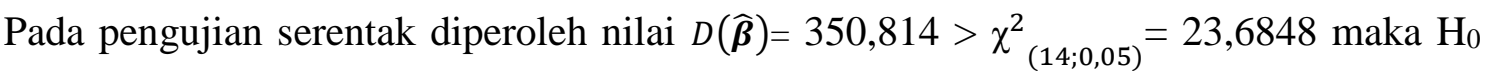
ditolak, sehingga dapat disimpulkan bahwa paling sedikit ada satu variabel independen yang berpengaruh terhadap jumlah kematian ibu hamil dan nifas di Jawa Tengah pada tahun 2017. Berdasarkan Tabel 11 diketahui bahwa pada kasus kematian ibu hamil $\mathrm{H}_{0}$ ditolak untuk variabel persentase ibu hamil melaksanakan Kunjungan Pertama ( $\left.\mathrm{X}_{1}\right)$, persentase ibu nifas mendapatkan pelayanan kesehatan nifas $\left(\mathrm{X}_{2}\right)$ dan persentase rumah tangga berperilaku hidup bersih dan sehat karena nilai $\left|Z_{\text {hitung }}\right|>$ dari $Z_{(0,025)}=1,96$, artinya variabel-variabel tersebut berpengaruh signifikan terhadap jumlah kematian ibu hamil di Jawa Tengah tahun 2017. Pada kasus jumlah kematian ibu nifas $\mathrm{H}_{0}$ ditolak untuk variabel persentase ibu hamil melaksanakan Kujungan Pertama $\left(\mathrm{X}_{1}\right)$, persentase ibu nifas mendapatkan pelayanan kesehatan nifas $\left(\mathrm{X}_{2}\right)$ dan persentase rumah tangga berperilaku hidup bersih dan sehat karena nilai $\left|Z_{\text {hitung }}\right|>$ dari $Z_{(0,025)}=1,96$, artinya variabel-variabel tersebut berpengaruh signifikan terhadap jumlah kematian ibu nifas di Jawa Tengah tahun 2017.

\subsection{Penentuan Model Terbaik dengan AIC}

Akaike Information Criterion (AIC) merupakan salah satu kriteria untuk menentukan model terbaik. Semakin kecil nilai AIC, maka model semakin baik dan layak untuk digunakan. Berdasarkan pemodelan yang telah dilakukan diperoleh nilai AIC pada setiap model sebagai berikut.

Tabel 12. Nilai AIC

\begin{tabular}{clc}
\hline \multicolumn{2}{c}{ Metode } & AIC \\
\hline Regresi Poisson & Kematian Ibu Hamil & 169,600 \\
Univariat & Kematian Ibu Nifas & 208,720 \\
& Model Pertama & 380,538 \\
Regresi Poisson & Model Kedua & 379,402 \\
Bivariat & Model Ketiga & 382,814 \\
\hline
\end{tabular}

Berdasarkan Tabel 12 nilai AIC pada Regresi Poisson Bivariat model dengan nilai AIC terkecil adalah model kedua dengan nilai AIC sebesar 379,402 sehingga model kedua merupakan model terbaik.

\section{PENUTUP}

\subsection{KESIMPULAN}

Berdasarkan analisis dan pembahasan dapat diambil kesimpulan sebagai berikut:

1. Pada Regresi Poisson Univariat kasus kematian ibu hamil terdapat tiga variabel independen yang berpengaruh signifikan yaitu variabel persentase ibu hamil 
melaksanakan Kunjungan Pertama $\left(\mathrm{X}_{1}\right)$, persentase ibu nifas mendapatkan pelayanan kesehatan nifas $\left(\mathrm{X}_{6}\right)$ dan persentase rumah tangga berperilaku hidup bersih dan sehat, sedangkan untuk kasus kematian ibu nifas terdapat dua variabel independen yang berpengaruh signifikan yaitu variabel persentase ibu hamil melaksanakan Kunjungan Pertama $\left(\mathrm{X}_{1}\right)$ dan persentase ibu nifas mendapatkan pelayanan kesehatan nifas $\left(\mathrm{X}_{6}\right)$.

2. Variabel jumlah kematian ibu hamil dan jumlah kematian ibu nifas mengikuti Distribusi Poisson dan memiliki korelasi yang signifikan. Selain itu, antara variabel independennya tidak memiliki keterkaitan yang erat atau tidak terjadi multikolinieritas sehingga variabel jumlah kematian ibu hamil dan nifas dapat dimodelkan dengan Regresi Poisson Bivariat.

3. Model terbaik dalam Regresi Poisson Bivariat adalah model kedua dengan nilai AIC sebesar 379,402, dengan model sebagai berikut

$$
\begin{aligned}
& \hat{\lambda}_{1} *=\exp \left(36,404-0,044 X_{1}-0,036 X_{2}-0,003 X_{3}-0,166 X_{4}+0,021 X_{5}-0,112 X_{6}-0,040 X_{7}\right) \\
& \hat{\lambda}_{2} *=\exp \left(812,983-0,016 X_{1}-0,042 X_{2}+0,024 X_{3}-0,030 X_{4}-0,003 X_{5}-0,031 X_{6}-0,018 X_{7}\right) \\
& \hat{\lambda}_{3} *=\exp \left(-1088,9-0,192 X_{1}+0,231 X_{2}-0,022 X_{3}+11,031 X_{4}-0,009 X_{5}-0,114 X_{6}-0,024 X_{7}\right) \\
& \text { Model untuk jumlah kematian ibu hamil adalah sebagai berikut. } \\
& \mathrm{E}\left(Y_{1}\right)=\exp \left(36,404-0,044 X_{1}-0,036 X_{2}-0,003 X_{3}-0,166 X_{4}+0,021 X_{5}-0,112 X_{6}-0,040 X_{7}\right)+ \\
& \quad \exp \left(-1088,9-0,192 X_{1}+0,231 X_{2}-0,022 X_{3}+11,031 X_{4}-0,009 X_{5}-0,114 X_{6}-0,024 X_{7}\right) \\
& \text { Model untuk jumlah kematian ibu nifas adalah sebagai berikut. } \\
& \mathrm{E}\left(Y_{2}\right)=\exp \left(812,983-0,016 X_{1}-0,042 X_{2}+0,024 X_{3}-0,030 X_{4}-0,003 X_{5}-0,031 X_{6}-0,018 X_{7}\right)+ \\
& \quad \exp \left(-1088,9-0,192 X_{1}+0,231 X_{2}-0,022 X_{3}+11,031 X_{4}-0,009 X_{5}-0,114 X_{6}-0,024 X_{7}\right)
\end{aligned}
$$

\section{DAFTAR PUSTAKA}

[Bappenas] Badan Perencanaan Pembangunan Nasional. 2014. Rencana Pembangunan Jangka Menengah Nasional 2015-2019: Buku I Agenda Pembangunan Nasional. Jakarta: Badan Perencanaan Pembangunan Nasional.

Bahiyatun. 2008. Buku Ajar Asuhan Kebidanan Nifas Normal. Jakarta: Penerbit Buku Kedokteran EGC.

Bozdogan, H. 2000. Akaike's Information Criterion and Recent Developments in Information Complexity. Mathematical Psychology.

Brase, C.H. dan Brase, C.P. 2011. Understandable Statistics: Concepts and Methods. New York: Cengage Learning.

Cameron, A.C. dan Trivedi, K.P. 1998. Regression Analysis of Count Data.USA: Cambridge University Press.

[Dinkes Jateng] Dinas Kesehatan Provinsi Jawa Tengah. 2018. Profil Kesehatan Provinsi Jawa Tengah Tahun 2017. Semarang: Dinas Kesehatan Provinsi Jawa Tengah.

Karlis, D. dan Ntzoufras, I. 2005. Bivariate Poisson and Diagonal Inflated Bivariate Poisson Regression Models in R. Journal of Statistical Software Vol. 14, No.10 : Hal 1-36.

[Kemenkes RI] Kementerian Kesehatan Republik Indonesia. 2018. Profil Kesehatan Indonesia Tahun 2017. Jakarta: Republik Indonesia.

Myers, M. V. 1990. Generalized Linear Model with Applications in Engineering and Sciences, 2th Edition.New Jersey: John Wiley \& Sons.

Prawirohardjo, S. 2009. Ilmu Kebidanan. Jakarta: PT. Bina Pustaka Sarwono Prawirohardjo 